\title{
PRESENT VALUE TESTS OF AN INTERTEMPORAL MODEL OF THE CURRENT ACCOUNT
}

\author{
Steven M. SHEFFRIN and Wing Thye WOO* \\ University of California at Davis, Davis, CA 95616, USA \\ Received February 1989, revised version received February 1990
}

This paper first demonstrates that in a simple intertemporal open economy model, the current account is equal to the expected decline of the present discounted value of net output of a country. Net output is defined as gross domestic product less the sum of investment plus government spending. It then uses econometric methods for present value models to analyze the current account for four countries. In two of these countries, the model does a satisfactory job of explaining the current account.

\section{Introduction}

Recent work on the determination of the current account has increasingly taken the perspective of intertemporal allocation of consumption. Earlier work by Greenwood (1983) and Sachs (1982) emphasized this approach and Frenkel and Razin (1988) and Obstfeld (1986), among others, have extended the basic model in a variety of directions.

Compared with the theoretical literature, there has been relatively little empirical work on simple versions of the model and the results in the literature have been conflicting and difficult to interpret. Ahmed (1986) and Sachs (1982) provide evidence in support of the approach by studying the relationship of the current account with government spending and investment, respectively. Dwyer (1986) finds evidence against the approach using data on budget deficits, while Johnson (1986) also rejected the model using an Euler equation approach. Sheffrin and Woo (1990) found mixed results; while they could not reject overidentifying restrictions for some countries, their estimates of discount rates were very imprecise.

Part of the difficulties in the empirical work in this literature are similar to those encountered in estimation of rational expectation models of the consumption function. Tests of the hypothesis are very sensitive to the

\footnotetext{
*The authors wish to thank participants at seminars at Berkeley, UC Davis, and the India Statistical Institute for helpful comments. Valuable suggestions from two anonymous referees and Robert Hodrik were incorporated into the final version.
}

0022-1996/90/\$03.50 (C) 1990-Elsevier Science Publishers B.V. (North-Holland) 
methods used to handle the evident nonstationarities of the relevant economic time series. Simple detrending can lead to spurious rejections [Mankiw and Shapiro (1985)], while first differencing of all variables is inappropriate in systems in which variables are cointegrated [Engle and Granger (1987)]. Statistical inference with nonstationary regressors is also highly sensitive to incidental parameters [West (1988)]. Finally, even if the models are rejected statistically, we often wish to know whether they provide reasonable approximations to the economic time series and the reasons why the models break down.

This paper uses an econometric approach recently developed by Campbell and Shiller (1987) and Campbell (1987) to test a simple version of an intertemporal current account model. Their approach provides both a convenient treatment of nonstationarity and also provides an illuminating perspective on the empirical performance of the model. Campbell (1987) has shown that the standard rational expectations consumption function has the implication that consumers will 'save for a rainy day' or that savings increase when expected future labor income is expected to decrease. We derive and test a similar implication for the open economy, namely that the current account should be equal to the expected future decline in a country's net output, defined as GDP less the sum of investment plus government purchases.'

Section 2 of the paper outlines the theoretical model and the empirical approach to testing the model. Formal statistical tests as well as measures of how well the models perform for four countries are given in section 3 . The final section discusses the results and suggests possible extensions of our approach.

\section{Theory and econometric methods}

In a small open economy facing a given world interest rate, the consumption decision can be made independent of any production decision. This basic decentralization result is at the heart of all models of small open economies. Blanchard (1983) studies a particular deterministic version of this model in which domestic investment decisions depend on the difference between the marginal product of capital and the world interest rate, whereas the aggregate consumption decision depends solely on a country's wealth.

The model we study in this paper permits a wide variety of structures but preserves the essential feature that consumption depends solely on a country's wealth. The key variable that consumers must forecast is what we term net output $(N O)$ which is defined to be GDP, $y$, less the sum of

\footnotetext{
${ }^{1}$ After completing an initial version of this paper, we discovered work by Ghosh (1988) which also applied Campbell's methods to the current account. Ghosh used these methods to provide benchmark estimates of the variance of an 'optimal' current account but did not study the timeseries properties as in our work. We discuss his idea further in the text below.
} 
investment, plus government purchases, $g+i$. The present discounted value of a country's net output plus its stock of external assets at any point in time constitutes its wealth. In our empirical work, the only restriction we will place on net output is that its first difference be stationary. This is an assumption which is satisfied in the data.

We first derive the condition which must be imposed in order to prevent external lending from becoming a Ponzi scheme. Consider the consequences of a country lending $\$ 1$ at the world interest rate, $r$, and continuing to lend every period to cover both principal and interest. This will cause the stock of external assets to grow at the rate of $(1+r)$. Obviously it is suboptimal for the lender to roll over the principal and capitalize the interest payments forever. The lender's refusal to finance a Ponzi scheme means that she will demand that the net present value of her foreign asset position be zero, i.e. full repayment of her lending. In the infinite horizon case, her demand translates to:

$$
\beta^{i} b_{t+i}=0, \text { as } i \text { goes to infinity, }
$$

where $\beta=1 /(1+r)$ and $b_{t+i}$ is the stock of external assets at the beginning of period $t+i$.

The stock of external assets evolves according to the equation:

$$
b_{t+1}=(1+r) b_{t}+\left[y_{t}-c_{t}-i_{t}-g_{t}\right],
$$

where the last term is the excess of output over spending, or the trade balance. ${ }^{2}$ Solving (2) forward and using the transversality condition (1), we obtain:

$$
b_{t}=-\sum_{i=1}^{\infty} \beta^{i} x_{t+i-1}
$$

where $x_{t+i}=y_{t+i}-c_{t+i}-i_{t+i}-g_{t+i}=$ net exports. Thus, at any point in time the stock of external assets equals the present discounted value of the stream of future trade deficits. ${ }^{3}$

The agent's intertemporal budget constraint can be derived by using the GDP identity:

$$
c_{t+i-1}=y_{t+i-1}-i_{t+i-1}-g_{t+i-1}-x_{t+i-1} \text {. }
$$

Discounting each term by $\beta^{i}$ and summing from 1 to $\infty$, we obtain:

\footnotetext{
${ }^{2}$ The timing conventions follow Flavin (1981) and Campbeil (1987). Wealth is measured at the beginning of the period, interest accrues during the period, and all income and spending occur at the end of the period.

${ }^{3}$ Solving (2) backwards would lead to an expression for the stock of external assets in terms of past trade surpluses.
} 


$$
\sum_{i=1}^{\infty} \beta^{i} c_{t+i-1}=\sum_{i=1}^{\infty} \beta^{i}\left[y_{t+i-1}-i_{t+i-1}-g_{t+i-1}\right]-\sum_{i=1}^{\infty} \beta^{i} x_{t+i-1} .
$$

Using (3), the intertemporal budget constraint can be written as:

$$
\sum_{i=1}^{\infty} \beta^{i} c_{t+i-1}=\sum_{i=1}^{\infty} \beta^{i}(N O)_{t+i-1}+b_{t}
$$

where $N O=$ net output $=y-i-g$. Net output is random and the source of uncertainty in the model.

A representative consumer will maximize an intertemporal utility functional of the form:

$$
E_{0}\left\{\sum_{i=0}^{\infty} \beta^{i} u\left[c_{i}\right]\right\}
$$

by choosing planned consumption subject to the constraint in eq. (6), treating net output as a random variable. Expectations are taken with respect to an information set $I_{0}$. In general, closed-form solutions do not exist for a consumption function under uncertainty. If we assume that the utility function can be approximated by a quadratic, then consumption will be proportional to expected wealth, or:

$$
c_{t}=r\left\{b_{t}+\left(\frac{1}{1+r}\right) \sum_{i=0}^{\infty}\left(\frac{1}{1+r}\right)^{i} E_{t}\left(N O_{t+i}\right)\right\} .
$$

Eq. (7) is the open economy rational expectations consumption function. As in Hall (1988), planned consumption is constant but actual consumption will change as the stochastic processes in the economy evolve.-

The closed-form consumptiuon function in eq. (7) is linear in expected future net output and thus can be combined with forecasts from a vector autoregression to test the model. In addition to formal test statistics, we can also derive period-by-period predictions of the current account and compare it with the actual behavior of the current account. This is the payoff for the assumptions used to derive eq. (7). More general conditions for consumer optimization can be tested by Euler equation methods. However, they do not yield predictions for current period consumption, only predictions conditional on future consumption.

In recent years there has been extensive work on the closed economy consumption function to relax the assumptions implicit in eq. (7). However, as Flavin (1988, pp. 8-9) argues, 'relaxing these assumptions has yet to produce much empirical improvement over the original formulation'. Hall (1988), for example, in an empirical analysis of the consumption-beta model, finds no effective contribution of the expected interest rate in explaining the 
change in the log of consumption. Since the empirical literature to date does not suggest an important role for expected interest rate movements, it appears useful to analyze the current account with the standard rational expectations consumption function.

We note, however, that in a small open economy there may be scope for additional effects through the real interest channel. In a model with traded and nontraded goods, Dornbusch (1983) has shown that the appropriate interest rate for a country is the world interest rate multiplied by the expected rate of change in the price of tradables to nontradables. Thus, expected changes in the real exchange rate can affect aggregate consumption. Closed-form solutions for the consumption function in this case, however, do not exist because both the effective interest rate and net output will then be random. ${ }^{4}$ While the Dornbusch model is suggestive for future research, it cannot be readily incorporated into the present value framework employed in this paper.

Our theory does not require us to specify any specific processes for the vector $\left(y_{t}, i_{t}, g_{t}\right)$; this feature of our model allows us to encompass a wide variety of theories. As examples, Sachs (1981) and Blanchard (1983) discuss the case in which productivity shocks lead a country to borrow from abroad and increase investment to take advantage of the gap between the world interest rate and the (higher) marginal productivity of capital. The extra output earned through this investment will finance repayment of the debt at a later date. In another example, suppose that it is impossible to change tax rates, but government spending is temporarily high. Rather than cutting consumption fully to accommodate the higher government spending, the level of existing consumption is maintained by borrowing from abroad. Finally, any temporary fall in output which does not directly change investment opportunities will also lead borrowing from abroad. Our model encompasses all these cases as well as all their combinations and related cases.

We note that by deriving the intertemporal budget constraint for the consumer from the summing and discounting of the GDP identity, eq. (4), we have forced the government to balance its budget in the present discounted value sense. In short, our model embodies the Ricardian Equivalence Principle (REP). An implication of the REP is that holding the path of government spending constant, changes in simply the timing of taxes will not change consumption or the current account.

Before turning to the econometric methods, it is instructive to relate the theory developed above to the debate over capital mobility. Feldstein and Horioka (1980) initiated the debatc by noting that the correlation between total domestic savings and domestic investment is very high in most

${ }^{4}$ For a discussion of consumption under uncertainty, see Blanchard and Fisher (1989, ch. 6). 
developed countries, which suggested to them that capital was not very mobile. Since the current account is the difference between total domestic savings and investment, their argument also implies that the variance of the current account for typical developed countries is too small to be consistent with a high degree of capital mobility. The problem with this argument, as first noted by Obstfeld (1986), is that it ignores the fact that common shocks may effect both savings and investment in each country and thus a positive correlation between savings and investment in each country is possible even with perfect capital mobility.

In the model developed in this paper there are no impediments to the flow of capital. A country can borrow freely to smooth consumption, subject to the no-Ponzi condition, at fixed world interest rates. As Ghosh (1988) observed, the variance of the current account in this model provides a natural benchmark with which to compare the variance of the actual current account. ${ }^{5}$ Thus, the statistical performance of the consumption-smoothing model can also shed light on the debate on capital mobility.

Following the lead of Campbell (1987), we now derive the useful expression for the current account $(C A)$, the sum of the trade balance plus interest income on external assets:

$$
C A_{t}=y_{t}+r b_{t}-i_{t}-g_{t}-c_{t}=N O_{t}+r b_{t}-c_{t} \text {. }
$$

Using the expression from (7) for consumption, this can be re-written as:

$$
\begin{aligned}
C A_{t} & =-\left(\frac{r}{1+r}\right) \sum_{i=0}^{\infty}\left(\frac{1}{1+r}\right)^{i} E_{t}\left(N O_{t+i}-N O_{t}\right) \\
& =-\sum_{i=1}^{\infty}\left(\frac{1}{1+r}\right)^{i} E_{t}\left(\Delta N O_{t+i}\right) .
\end{aligned}
$$

The last equality can be verified by writing out the individual terms for $N O_{t+i}$. This equation has a simple interpretation. A country will run a current account surplus only if it expects its net output to be falling in the future. The analogy to household savings is instructive; as Campbell has shown, an implication of the rational expectations permanent income model is that households save when they expect their future labor income to decline. In our model, net output plays the role of labor income and the current account the role of savings. For example, if a country is experiencing

\footnotetext{
${ }^{5}$ Ghosh tests for the equality between the variance of the actual current account and the predictions of the current account from the model. He could not reject the hypothesis of equality.
} 
a temporary productivity increase, the optimal response is to run a current account surplus. This will insure that planned consumption will be smoothed in the economy.

The expression for the current account also has an important econometric implication. If net output is stationary in first differences, then the current account will also be statonary in its level. Although consumption, interest income from external assets, and net output in this economy will be stationary only in first differences (nonstationary in levels), the current account will be stationary. This is an example of a cointegrated system in which a linear combination of net output, interest income and consumption (the current account) has a lower order time-series representation than each component.

The cointegration property of the data allows us to estimate and test the restrictions of the theory in a vector autoregression (VAR) with net output and the current account. If net output is stationary in first differences, then the current account will also be stationary and we have achieved stationarity in our representation while preserving important information in the levels of variables with the current account. ${ }^{6}$

To test the implications of the model, we first estimate a VAR of the form:

$$
\left[\begin{array}{c}
\Delta N O \\
C A
\end{array}\right]_{t}=\left[\begin{array}{ll}
a(L) & b(L) \\
c(L) & d(L)
\end{array}\right]\left[\begin{array}{c}
\Delta N O \\
C A
\end{array}\right]_{t-1}+\left[\begin{array}{c}
u_{t} \\
v_{t}
\end{array}\right]
$$

With the annual data we use, a second-order VAR captures the time-series properties of the series. The VAR can be rewritten as:

$$
\left[\begin{array}{c}
\Delta N O_{1} \\
\Delta N O_{t-1} \\
C A_{t} \\
C A_{t-1}
\end{array}\right]=\left[\begin{array}{cccc}
a_{1} & a_{2} & b_{1} & b_{2} \\
1 & 0 & 0 & 0 \\
c_{1} & c_{2} & d_{1} & d_{2} \\
0 & 0 & 1 & 0
\end{array}\right]\left[\begin{array}{c}
\Delta N O_{t-1} \\
\Delta N O_{t-2} \\
C A_{t-1} \\
C A_{t-2}
\end{array}\right]+\left[\begin{array}{c}
u_{t} \\
0 \\
v_{t} \\
0
\end{array}\right],
$$

or, in compact notation, as $Z_{t}=A Z_{t-1}+w_{t}$, where $E\left(Z_{t+i}\right)=$ $A^{i} Z_{t}$. The data in this VAR is a subset $\left(H_{t}\right)$ of the data $\left(I_{t}\right)$, available to the economic agents and should simply be viewed as a statistical relationship.

Using (11), the restrictions on the current account in (9) can be expressed as:

${ }^{6}$ For a further discussion of cointegration properties in this problem, see Campbell (1987). 


$$
g^{\prime}=-\sum_{i=1}^{\infty}\left(\frac{1}{1+r}\right)^{i} h^{\prime} A^{i}
$$

where

$$
g=\left[\begin{array}{l}
0 \\
0 \\
1 \\
0
\end{array}\right] \text { and } h=\left[\begin{array}{l}
1 \\
0 \\
0 \\
0
\end{array}\right] \text {. }
$$

These restrictions are obtained by projecting eq. (9) onto the information set, $H_{i}$. This yields the restrictions on the VAR given in (12). The intuition behind these restrictions is straightforward. These restrictions insure that for any $Z_{t}$, the current account (the left-hand side) equals minus the expected present value of declines in net output (the right-hand side).

For a given $Z_{t}$, the right-hand side of eq. (12) can be expressed as:

$$
C A_{t}^{\prime}=K Z_{t}
$$

where

$$
K=-h^{\prime}\left(\frac{1}{1+r}\right) A\left[1-\left(\frac{1}{1+r}\right) A\right]^{-1}
$$

This expression gives a forecast of the current account $\left(C A_{t}^{\prime}\right)$ based on the VAR. This can be compared with the actual current account to obtain an informal but useful characterization of how well the model performs.

While the formal restrictions in (12) appear complicated, they actually reduce to a very simple relationship. Define $R_{t}=C A_{t}-\Delta N O_{t}-(1+r) C A_{t}-1$. Then the restrictions simply state that $E\left(R_{t} \mid I_{t-1}\right)=0$, where $I_{t-1}$ is any information available at $t-1$. A slightly weaker version of the model can also be tested which allows for transitory consumption [an error in (7)] which is uncorrelated at all leads and lags with the other disturbances in the model. For this model, $E\left(R_{t} \mid I_{t-2}\right)=0$. Both hypotheses can be tested by constructing $R_{\mathrm{t}}$ and running appropriate regressions with lagged values of the stationary series, $\triangle N O$ and $C A .^{7}$

\footnotetext{
'Banerjee and Dolado (1988) discuss some of the problems in similar tests with nonstationary data.
} 


\section{Data, estimation, and results}

In our empirical work, we examine annual data for four countries: Belgium, Canada, Denmark and the United Kingdom (BCDU). All the data are from the International Financial Statistics and cover the period 1955-85. This period insured full and consistent coverage of the key series. The four countries were selected to meet two criteria. First, we wanted the countries to be relatively free of capital controls. We examined annual reports of the IMF's Exchange Arrangements and Exchange Restrictions to choose the countries. Second, our theory was based on capital mobility and assumed immobile labor. We thus eliminated countries (such as Germany and Switzerland) with significant international labor mobility.

The net output series was constructed by subtracting the sum of investment and government purchases from GDP and deflating by either the GNP (or GDP) deflator and also by population. The series for the current account was constructed by subtracting from GNP the sum of consumption, investment, and government spending, and then converting the data to real per capita terms. We chose this method over the two alternatives of using the current account data from the balance of payments or constructing a net foreign asset position and imputing income. The former procedure requires an arbitrary allocation of some of the 'errors and omissions' into the current account. The latter procedure suffers from lack of available interest rates as well as difficulties in constructing net asset positions. Gross National Product does include both net capital and labor payments from abroad but, as noted above, the latter is not accounted for in the theory developed in this paper. We included only those countries for which the labor component was negligible.

A first step in the research is to check if the statistical assumptions that net output is stationary in the first differences and the current account is stationary in levels is reasonable. The standard procedure to examine these assumptions is to run regressions of the form:

$$
\Delta N O_{t}=a+b_{1} \cdot \Delta N O_{t-1}+b_{2} \cdot \Delta N O_{t-2}+c \cdot N O_{t-1}+d \cdot \text { time }+\eta_{t}
$$

and test whether the coefficient $c$ is negative and significantly different than zero using the appropriate Dickey-Fuller statistics. For the net output series, we would like to fail to reject the null hypothesis that $c$ is zero; for the current account series, we would like to reject the null hypothesis and accept the alternative that the current account is stationary in levels.

The results of the statistical tests are somewhat ambiguous. For the BCDU countries, the ratios of the coefficient to the standard error for $c$ in the net output equation for the period $1957-85$ were $-2.71,-2.78,0.98$, and 
Table 1

Means. 1955-85.

\begin{tabular}{lcc}
\hline & $\Delta N O$ & $C A$ \\
\hline Belgium & 0.11 & -0.13 \\
& $(3.25)$ & $(5.38)$ \\
Canada & 0.14 & -0.12 \\
& $(0.95)$ & $(0.11)$ \\
Denmark & 0.67 & -1.29 \\
& $(0.63)$ & $(1.23)$ \\
United Kingdom & 0.04 & 0.02 \\
& $(0.04)$ & $(0.05)$ \\
\hline
\end{tabular}

Note: Standard errors in parentheses.

-4.85 , respectively. Except for the United Kingdom, these are below the critical value of approximately 3.6 necessary to reject the null hypothesis at the 5 percent level. ${ }^{8}$ However, the first two values are high enough to suggest that it may be difficult to decide between stationarity in first differences or stationarity in levels.

For the current account, similar regressions yielded test statistics for the BCDU countries of $-2.5,-3.2,-2.1$, and -2.9 , respectively. While the null hypothesis cannot be rejected at the 5 percent level, the test statistics are high enough to again suggest that it is difficult to distinguish between stationarity in levels or in differences. We proceed with the assumption that net output was stationary in differences and the current account stationary in levels. ${ }^{9}$

Table 1 presents the means for the first difference of net output and the current account. The theory suggests that in large samples the current account should be approximately equal to $-(1 / r)$ times the mean of the change in net output. For three of the countries, the sign is correct but the magnitudes are much too small. However, the standard errors are large. Essentially, this prediction rests heavily on the representative individual assumption in which all trends in net output will be fully internalized by the country. It would not allow a country to have a persistent current account surplus in the sample with an upwards trend in net output. Similar restrictions fail to hold in studies of consumption in which aggregate savings are positive in the presence of an upward trend in labor income. As has been recognized in the consumption literature, aggregate positive savings can exist

\footnotetext{
${ }^{8}$ West (1987) argues that if the null hypothesis is stationary around a time trend, then considerations of statistical power suggest including a time trend in the regression. Without the time trend, the U.K. statistic is far below the critical value and the other statistics are lower as well.

${ }^{9}$ Because the consumption function is linear in the sum of changes in net output, the change in net output (rather than the change in the logs) must be stationary.
} 
Table 2

Belgium.

\begin{tabular}{|c|c|c|c|c|c|c|c|c|}
\hline & & & \multicolumn{4}{|c|}{ Tests on $R_{\mathrm{I}}$} & \multicolumn{2}{|c|}{$K$ vector } \\
\hline & \multicolumn{2}{|l|}{ VAR } & \multicolumn{2}{|l|}{$I_{t-1}$} & \multicolumn{2}{|l|}{$I_{1-2}$} & $(4 \%)$ & $(14 \%)$ \\
\hline & $\triangle N O_{t}$ & $C A_{t}$ & $4 \%$ & $14 \%$ & $4 \%$ & $14 \%$ & \multicolumn{2}{|c|}{$\hat{C} A_{t-1}=K Z_{t-1}$} \\
\hline$\Delta N O_{t-1}$ & $\begin{array}{c}0.25 \\
(0.22)\end{array}$ & $\begin{array}{c}-0.24 \\
(0.27)\end{array}$ & $\begin{array}{c}-0.48 \\
(0.56)\end{array}$ & $\begin{array}{c}-0.48 \\
(0.20)\end{array}$ & & & $\begin{array}{c}-0.55 \\
(0.42)\end{array}$ & $\begin{array}{c}-0.49 \\
(0.34)\end{array}$ \\
\hline$\Delta N O_{1-2}$ & $\begin{array}{c}0.17 \\
(0.19)\end{array}$ & $\begin{array}{c}0.36 \\
(0.18)\end{array}$ & $\begin{array}{c}0.19 \\
(0.18)\end{array}$ & $\begin{array}{c}0.19 \\
(0.18)\end{array}$ & $\begin{array}{c}0.05 \\
(0.12)\end{array}$ & $\begin{array}{c}0.04 \\
(0.18)\end{array}$ & $\begin{array}{c}-0.02 \\
(0.25)\end{array}$ & $\begin{array}{r}-0.06 \\
(0.22)\end{array}$ \\
\hline$C A_{1-1}$ & $\begin{array}{c}-0.08 \\
(0.22)\end{array}$ & $\begin{array}{c}1.09 \\
(0.22)\end{array}$ & $\begin{array}{c}0.13 \\
(0.20)\end{array}$ & $\begin{array}{c}0.03 \\
(0.20)\end{array}$ & & & $\begin{array}{c}0.69 \\
(0.49)\end{array}$ & $\begin{array}{r}-0.52 \\
(0.39)\end{array}$ \\
\hline$C A_{1-2}$ & $\begin{array}{c}-0.06 \\
(0.22)\end{array}$ & $\begin{array}{c}-0.38 \\
(0.22)\end{array}$ & $\begin{array}{c}-0.31 \\
(0.21)\end{array}$ & $\begin{array}{c}-0.31 \\
(0.21)\end{array}$ & $\begin{array}{c}-0.15 \\
(0.18)\end{array}$ & $\begin{array}{c}-0.22 \\
(0.11)\end{array}$ & $\begin{array}{c}-0.16 \\
(0.28)\end{array}$ & $\begin{array}{r}-0.09 \\
(0.26)\end{array}$ \\
\hline$R^{2}$ & 0.15 & 0.70 & 0.24 & 0.32 & 0.05 & 0.12 & & \\
\hline$F$-statistic & & & 1.93 & 2.83 & 0.79 & 1.84 & & \\
\hline $\begin{array}{l}P \text {-value } \\
\chi^{2} \text {-statistic }\end{array}$ & & & 0.14 & 0.05 & 0.47 & 0.18 & $\begin{array}{l}0.30 \\
4.8\end{array}$ & $\begin{array}{l}0.12 \\
7.3\end{array}$ \\
\hline
\end{tabular}

Notes: Standard errors in parentheses; constants omitted in VAR; regressions are for 1957-85.

with trends in labor income when there is technical progress and younger generations are thereby born with a higher level of permanent income. Following Campbell, we allow for this possibility by removing the means from the current account and from the first difference of net output for the remainder of the analysis. We thus test only the dynamic restrictions of the theory which has been standard practice in the consumption literature.

The basic results from the estimation procedures are presented in tables 25. All tables have the same format. The first two columns give the coefficients and standard errors for the vector autoregressions. The next four columns present tests of the restrictions imposed by the theory on the VAR with information sets dated $t-1$ and $t-2$. These tests require that an interest rate be specified a priori. Results are presented for both 4 percent per year (a conventional estimate of the real rate on capital) and a higher rate of 14 percent per year. The choice of this higher rate was based on Bernanke's (1985) study in which a 14 percent rate was needed to rationalize consumption-income relations. The last two columns present estimates and standard errors of the $K$ vector in eq. (13) which maps $Z(t)$ into an estimate of the current account. Estimates of the $K$ vector are for both 4 and 14 percent discount rates. Standard errors for $K$ are calculated using numerical derivatives by the 'delta' method. ${ }^{10}$

It is also possible to calculate a $\chi^{2}$ statistic for the hypothesis that $K=[0,0,1,0]$. Let $\tilde{K}$ be the difference between the actual $K$ and the hypothesized value, then $\tilde{K}^{\prime}\left[\partial k^{\prime} \partial a V \partial k / \partial a^{\prime}\right]^{-1} \tilde{K}$ will be distributed $\chi^{2}$ with

\footnotetext{
${ }^{10}$ Deaton et al. (1989) provide a description of this method. It simply provides standard errors for a nonlinear function of the parameters.
} 
Table 3

Canada.

\begin{tabular}{|c|c|c|c|c|c|c|c|c|}
\hline & & & \multicolumn{4}{|c|}{ Tests on $R_{t}$} & \multicolumn{2}{|c|}{$K$ vector } \\
\hline & \multicolumn{2}{|l|}{ VAR } & \multicolumn{2}{|l|}{$I_{t-1}$} & \multicolumn{2}{|l|}{$I_{\mathrm{t}-2}$} & $(4 \%)$ & $(14 \%)$ \\
\hline & $\triangle N O$ & $C A_{t}$ & $4 \%$ & $14 \%$ & $4 \%$ & $14 \%$ & \multicolumn{2}{|c|}{$\hat{\hat{C}_{A_{t-1}}=K Z_{t-1}}$} \\
\hline$\Delta N O_{t-1}$ & $\begin{array}{c}-0.005 \\
(0.17)\end{array}$ & $\begin{array}{c}-0.002 \\
(0.011)\end{array}$ & $\begin{array}{c}-0.01 \\
(0.17)\end{array}$ & $\begin{array}{c}-0.01 \\
(0.17)\end{array}$ & & & $\begin{array}{c}0.38 \\
(0.15)\end{array}$ & $\begin{array}{c}0.31 \\
(0.10)\end{array}$ \\
\hline$\triangle N O_{t-2}$ & $\begin{array}{c}-0.52 \\
(0.17)\end{array}$ & $\begin{array}{c}-0.02 \\
(0.02)\end{array}$ & $\begin{array}{c}0.01 \\
(0.17)\end{array}$ & $\begin{array}{r}-0.49 \\
(0.17)\end{array}$ & $\begin{array}{c}0.50 \\
(0.16)\end{array}$ & $\begin{array}{c}0.49 \\
(0.16)\end{array}$ & $\begin{array}{c}0.39 \\
(0.14)\end{array}$ & $\begin{array}{c}0.35 \\
(0.09)\end{array}$ \\
\hline$C A_{t-1}$ & $\begin{array}{c}-0.03 \\
(1.70)\end{array}$ & $\begin{array}{c}0.49 \\
(0.19)\end{array}$ & $\begin{array}{c}-0.51 \\
(1.72)\end{array}$ & $\begin{array}{c}-0.61 \\
(1.71)\end{array}$ & & & $\begin{array}{c}-4.92 \\
(8.31)\end{array}$ & $\begin{array}{r}-2.50 \\
(3.91)\end{array}$ \\
\hline$C A_{t-2}$ & $\begin{array}{l}1.65 \\
(1.79)\end{array}$ & $\begin{array}{c}0.16 \\
(0.20)\end{array}$ & $\begin{array}{c}-1.48 \\
(1.81)\end{array}$ & $\begin{array}{c}-1.48 \\
(1.81)\end{array}$ & $\begin{array}{c}-1.79 \\
(1.43)\end{array}$ & $\begin{array}{r}-1.84 \\
(1.44)\end{array}$ & $\begin{array}{c}-2.10 \\
(2.73)\end{array}$ & $\begin{array}{r}-1.48 \\
(1.56)\end{array}$ \\
\hline $\begin{array}{l}R^{2} \\
F \text {-statistic }\end{array}$ & 0.28 & 0.37 & $\begin{array}{l}0.27 \\
223\end{array}$ & $\begin{array}{l}0.27 \\
225\end{array}$ & $\begin{array}{l}0.26 \\
4.76\end{array}$ & $\begin{array}{l}0.26 \\
479\end{array}$ & & \\
\hline $\begin{array}{l}F \text {-statistic } \\
P \text {-value }\end{array}$ & & & $\begin{array}{l}2.23 \\
0.09\end{array}$ & $\begin{array}{l}0.23 \\
0.09\end{array}$ & $\begin{array}{l}4.76 \\
0.02\end{array}$ & $\begin{array}{l}4.19 \\
0.02\end{array}$ & 0.005 & 0.001 \\
\hline$\chi^{2}$-statistic & & & & & & & 14.9 & 18.5 \\
\hline
\end{tabular}

Notes: Standard errors in parentheses; constants omitted in VAR; regressions are for 1957-85.

Table 4

Denmark.

\begin{tabular}{|c|c|c|c|c|c|c|c|c|}
\hline & & & \multicolumn{4}{|c|}{ Tests on $R_{t}$} & \multicolumn{2}{|c|}{$K$ vector } \\
\hline & \multicolumn{2}{|l|}{ VAR } & \multicolumn{2}{|l|}{$I_{t-1}$} & \multicolumn{2}{|l|}{$I_{\mathrm{t}-2}$} & $(4 \%)$ & $(14 \%)$ \\
\hline & $\Delta N O_{t-2}$ & $C A_{t}$ & $4 \%$ & $14 \%$ & $4 \%$ & $14 \%$ & \multicolumn{2}{|c|}{$\hat{C} A_{t-1}=K Z_{t-1}$} \\
\hline$\triangle N O_{1-1}$ & $\begin{array}{c}-0.43 \\
(0.20)\end{array}$ & $\begin{array}{c}-0.87 \\
(0.27)\end{array}$ & $\begin{array}{c}-0.43 \\
(0.24)\end{array}$ & $\begin{array}{r}-0.44 \\
(0.24)\end{array}$ & & & $\begin{array}{c}0.11 \\
(0.22)\end{array}$ & $\begin{array}{c}0.19 \\
(0.14)\end{array}$ \\
\hline$\triangle N O_{t-2}$ & $\begin{array}{c}-0.24 \\
(0.21)\end{array}$ & $\begin{array}{c}-0.05 \\
(0.20)\end{array}$ & $\begin{array}{c}0.19 \\
(0.26)\end{array}$ & $\begin{array}{c}0.19 \\
(0.26)\end{array}$ & $\begin{array}{c}0.53 \\
(0.23)\end{array}$ & $\begin{array}{c}0.62 \\
(0.24)\end{array}$ & $\begin{array}{c}0.18 \\
(0.14)\end{array}$ & $\begin{array}{r}0.16 \\
(0.11)\end{array}$ \\
\hline$C A_{t-1}$ & $\begin{array}{c}-0.05 \\
(0.17)\end{array}$ & $\begin{array}{c}0.71 \\
(0.22)\end{array}$ & $\begin{array}{c}-0.27 \\
(0.20)\end{array}$ & $\begin{array}{c}-0.38 \\
(0.20)\end{array}$ & & & $\begin{array}{c}0.52 \\
(0.33)\end{array}$ & $\begin{array}{c}0.34 \\
(0.19)\end{array}$ \\
\hline$C A_{t-2}$ & $\begin{array}{c}-0.15 \\
(0.16)\end{array}$ & $\begin{array}{c}0.002 \\
(0.22)\end{array}$ & $\begin{array}{c}0.15 \\
(0.20)\end{array}$ & $\begin{array}{c}0.15 \\
(0.20)\end{array}$ & $\begin{array}{c}0.017 \\
(0.124)\end{array}$ & $\begin{array}{c}-0.05 \\
(0.12)\end{array}$ & $\begin{array}{c}0.13 \\
(0.13)\end{array}$ & $\begin{array}{c}0.10 \\
(0.09)\end{array}$ \\
\hline $\begin{array}{l}R^{2} \\
F \text {-statistic }\end{array}$ & 0.25 & 0.64 & $\begin{array}{l}0.38 \\
3.77\end{array}$ & $\begin{array}{l}0.45 \\
4.94\end{array}$ & $\begin{array}{l}0.17 \\
274\end{array}$ & $\begin{array}{l}0.20 \\
3.27\end{array}$ & & \\
\hline $\begin{array}{l}F \text {-statistic } \\
P \text {-value } \\
\chi^{2} \text {-statistic }\end{array}$ & & & $\begin{array}{l}3.77 \\
0.02\end{array}$ & $\begin{array}{l}4.94 \\
0.01\end{array}$ & $\begin{array}{l}2.74 \\
0.08\end{array}$ & $\begin{array}{l}3.21 \\
0.05\end{array}$ & $\begin{array}{c}0.00 \\
40.2\end{array}$ & $\begin{array}{c}0.00 \\
70.3\end{array}$ \\
\hline
\end{tabular}

Notes: Standard errors in parentheses; constants omitted in VAR; regressions are for 1957-85.

four degrees of freedom where $\partial k / \hat{c} a$ is the matrix of derivatives of the $K$ vector with respect to the underlying parameters of the VAR $a$, and $V$ is the variance-covariance of the underlying parameters. The critical value for a $\chi^{2}(4)$ at the 5 percent level is 9.4 .

The model performs reasonably well for Belgium and Denmark but fails miserably for Canada and the United Kingdom. For Belgium, the model passes the tests on restrictions for both information sets with a 4 percent 
Table 5

United Kingdom.

\begin{tabular}{|c|c|c|c|c|c|c|c|c|}
\hline & & & \multicolumn{4}{|c|}{ Tests on $R_{t}$} & \multicolumn{2}{|c|}{$K$ vector } \\
\hline & \multicolumn{2}{|l|}{ VAR } & \multicolumn{2}{|l|}{$I_{t-1}$} & \multicolumn{2}{|l|}{$I_{t-2}$} & $(4 \%)$ & $\left(14^{\circ} \%\right)$ \\
\hline & $\triangle N O$ & $C A_{t}$ & $4 \%$ & $14 \%$ & $4^{0}{ }_{0}$ & $14 \%$ & \multicolumn{2}{|c|}{$\widehat{C A_{t-1}}=K Z_{t-1}$} \\
\hline$\Delta N O_{1-1}$ & $\begin{array}{c}-0.07 \\
(0.27)\end{array}$ & $\begin{array}{c}-0.53 \\
(0.21)\end{array}$ & $\begin{array}{c}-0.45 \\
(0.23)\end{array}$ & $\begin{array}{c}-0.45 \\
(0.23)\end{array}$ & & & $\begin{array}{c}-0.05 \\
(0.34)\end{array}$ & $\begin{array}{c}-0.03 \\
(0.30)\end{array}$ \\
\hline$\Delta N O_{1-2}$ & $\begin{array}{c}0.12 \\
(0.26)\end{array}$ & $\begin{array}{r}0.375 \\
(0.21)\end{array}$ & $\begin{array}{c}0.25 \\
(0.22)\end{array}$ & $\begin{array}{c}0.25 \\
(0.22)\end{array}$ & $\begin{array}{c}0.24 \\
(0.22)\end{array}$ & $\begin{array}{c}0.26 \\
(0.23)\end{array}$ & $\begin{array}{c}-0.09 \\
(0.27)\end{array}$ & $\begin{array}{c}-0.09 \\
(0.29)\end{array}$ \\
\hline$C A_{t-1}$ & $\begin{array}{c}0.10 \\
(0.27)\end{array}$ & $\begin{array}{c}1.12 \\
(0.21)\end{array}$ & $\begin{array}{c}-0.01 \\
(0.22)\end{array}$ & $\begin{array}{c}-0.11 \\
(0.22)\end{array}$ & & & $\begin{array}{c}0.06 \\
(0.43)\end{array}$ & $\begin{array}{c}0.03 \\
(0.37)\end{array}$ \\
\hline$C A_{t-2}$ & $\begin{array}{c}-0.13 \\
(0.26)\end{array}$ & $\begin{array}{c}-0.53 \\
(0.21)\end{array}$ & $\begin{array}{l}-0.40 \\
(0.22)\end{array}$ & $\begin{array}{c}-0.40 \\
(0.22)\end{array}$ & $\begin{array}{r}-0.40 \\
(0.16)\end{array}$ & $\begin{array}{c}-0.47 \\
(0.17)\end{array}$ & $\begin{array}{c}0.10 \\
(0.26)\end{array}$ & $\begin{array}{c}0.10 \\
(0.24)\end{array}$ \\
\hline $\begin{array}{l}R^{2} \\
F \text {-statistic }\end{array}$ & 0.01 & 0.57 & $\begin{array}{l}0.33 \\
3.07\end{array}$ & 0.40 & $\begin{array}{l}0.18 \\
300\end{array}$ & 0.23 & & \\
\hline $\begin{array}{l}P \text {-value } \\
\chi^{2} \text {-statistic }\end{array}$ & & & 0.03 & 0.01 & 0.07 & 0.03 & $\begin{array}{l}0.46 \\
9.7\end{array}$ & $\begin{array}{l}0.01 \\
13.1\end{array}$ \\
\hline
\end{tabular}

Notes: Standard errors in parentheses; constants omitted in VAR; regressions are for 1957-85.

discount rate. At the 14 percent discount rate, the model can just be rejected at the 5 percent level with the $t-1$ information set. The $K$ vector should ideally be $\left(\begin{array}{llll}0 & 0 & 1 & 0\end{array}\right)$, that is, placing all weight on the contemporaneous value of the current account. The best $K$ vector occurs with the 4 percent discount rate and places a 0.69 weight on the current account with a standard error of 0.49 .

Fig. 1 plots the actual current account for Belgium against the predicted current account using the estimated $K$ vector. The actual current account is more volatile than the predictions from the unrestricted VAR. If the actual current account is too volatile, this implies that consumption is 'too smooth'. " Additional support for this interpretation comes from the fact that the model performs best for lower discount rates; traditionally, higher discount rates are used to rationalize consumption which is too volatile. With higher interest rates, future income is discounted more heavily relative to current income and thus permanent income becomes more closely related to current income. Since our model for Belgium performs better at lower interest rates, it suggests that consumers do not discount the future very heavily and thus place too little weight on current income.

For Denmark, the restrictions are rejected with the larger information set at the 5 percent level and at the 10 percent level with the smaller information set. The discount rates do not appear to matter too much, although the model again performs slightly better at the lower discount rate. The $K$

\footnotetext{
${ }^{11}$ Deaton (1986) finds similar results for consumption.
} 


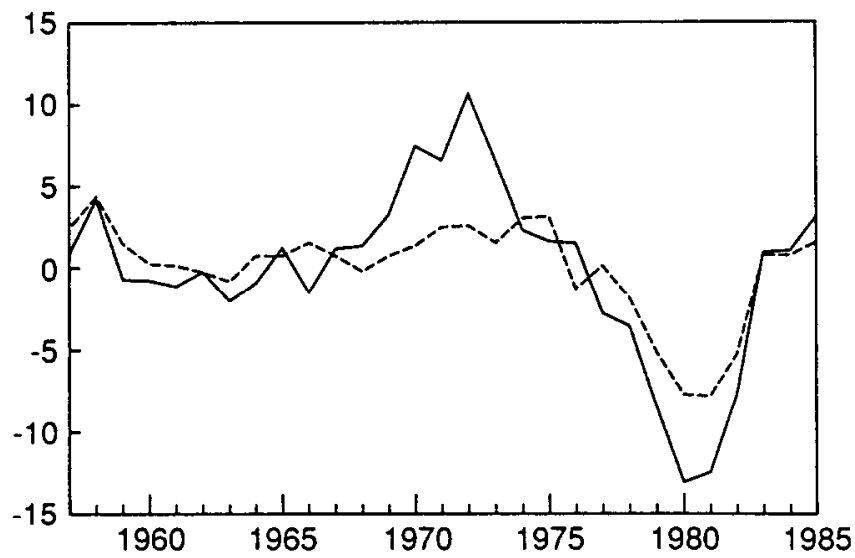

Fig. 1. Belgium. The solid line is the actual current account while the dotted line is the forecasted current account from the VAR, 1957-85.

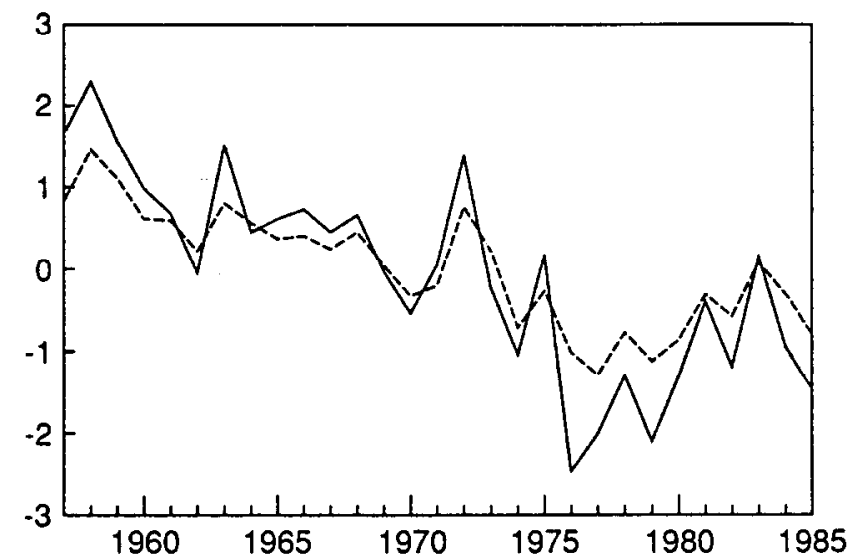

Fig. 2. Denmark. The solid line is the actual current account while the dotted line is the forecasted current account from the VAR, 1957-85.

vectors are quite reasonable and, as fig. 2 indicates, the predicted current account tracks the actual current account reasonable well.

For both the United Kingdom and Canada the model fails all the tests and the $K$ vectors are not reasonable. There are two problems for the United Kingdom. First, the response of the current account to the first oil shock is so severe that it distorts the time-series models. Second, the equation for the change in net output in the VAR has no explanatory power. It is not as clear why the model performs so poorly for Canada. As fig. 4 indicates, the actual current account is very stable but the predicted current account 


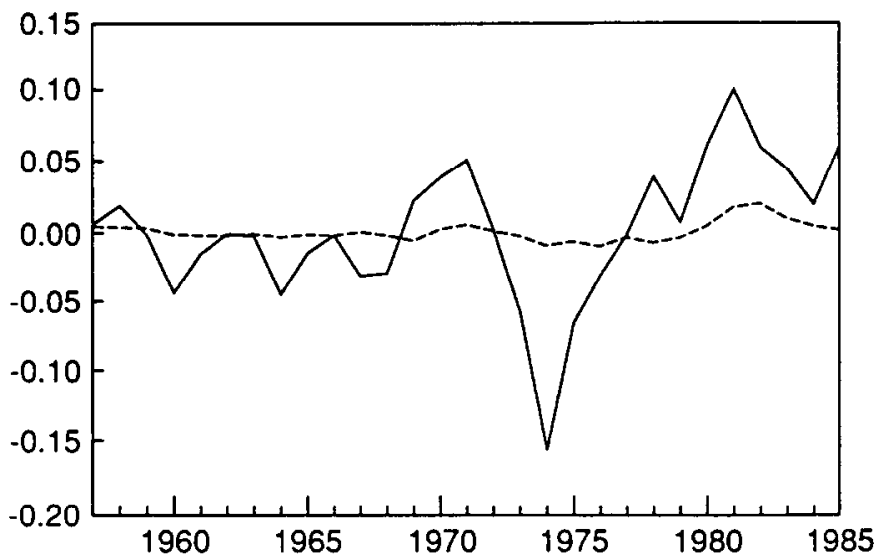

Fig. 3. United Kingdom. The solid line is the actual current account while the dotted line is the forecasted current account from the VAR, 1957-85.

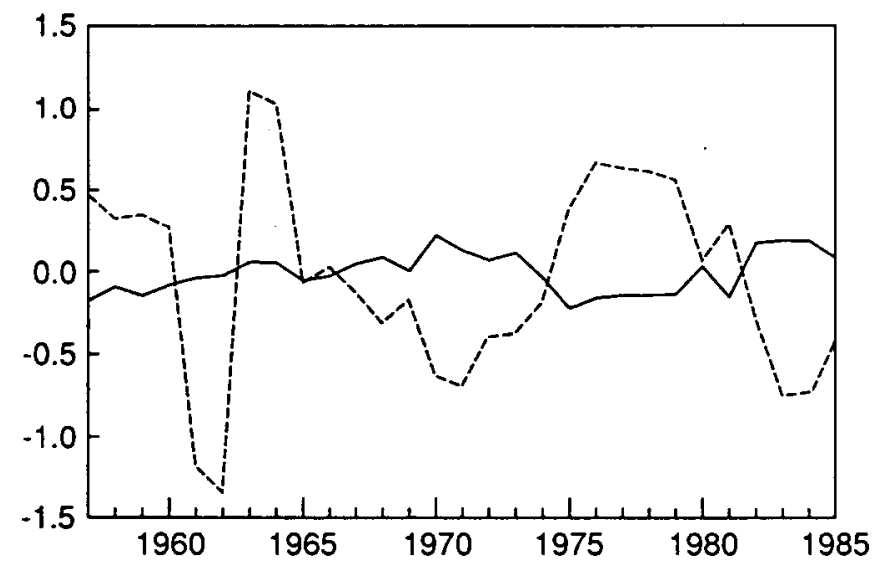

Fig. 4. Canada. The solid line is the actual current account while the dotted line is the forecasted current account from the VAR, 1957-85.

fluctuates dramatically. The equation for the change in net output places no weight on the first lag but a high negative value for the second lag. This unusual pattern is perhaps the source of the unusual $K$ vector.

With one exception, the $\chi^{2}$ statistics corroborate this story. The null hypothesis that $K=[0,0,1,0]$ is not rejected for Belgium and is rejected for the United Kingdom and Canada at the 5 percent level. However, the hypothesis is soundly rejected for Denmark which, on other grounds, appears to fit the theory. The reason for this appears to be that the standard errors 
on the coefficients are smaller for Denmark than the other countries. Since the model fits well, it is easier to reject the null hypothesis.

\section{Conclusions}

The simple intertemporal current account model performed reasonably for several countries indicating that extensions of this approach may be useful. Both the test statistics and the graphs provide revealing information about the model's adequacy. But there are several areas in which this approach should be extended.

First, other sources of wealth, such as oil reserves, can potentially be included in the model. This would potentially allow the model to track the period through the oil shocks in the 1970s when some countries reacted sharply to OPEC price increases.

Second, it would be useful to relax the assumption of a single good and distinguish, perhaps, between tradable and nontradable goods as some of the models in Dornbusch (1983) and Frenkel and Razin (1988). The real exchange then would become an important variable in the model.

Finally, it would be useful to extend the model to environments in which Ricardian equivalence does not hold either through overlapping generations or stochastic lifetimes. This would then allow an investigation of the role of government debt in the empirical determinations of the current account. These extensions would take us far beyond the present-value framework in the paper. However, upon leaving this present-value framework, richer models of consumption could then be considered. These could include models with habit formation [Constantinedes (1988)], near-rationality models [Cochrane (1989)], or models with some liquidity constrained consumers [Campbell and Mankiw (1989)].

One final caution. It is well known that the current account data contain errors. Precise statistical techniques such as used in this paper may highlight data errors as well as failures of the underlying model.

\section{References}

Ahmed, S., 1986, Temporary and permanent government spending in an open economy, Journal of Monetary Economics 17, 197-224.

Banerjee, A. and J. Dolado, 1988, Tests of the life cycle-permanent income hypothesis in the presence of random walks: Asymptotic theory and small-sample interpretations, Oxford Economic Papers 40, 610-633.

Bernanke, B., 1985, Adjustment costs, durables, and aggregate consumption, Journal of Monetary Economics 15, 41-68.

Blanchard, O., 1983, Debt and the current account deficit in Brazil, in: P.A. Armella, R. Dornbusch and M. Obstfeld, eds., Financial policies and the world capital market: The problem of Latin American countries (University of Chicago Press, Chicago, IL) 187-197.

Blanchard, O. and S. Fisher, 1989, Lectures in macroeconomics (MIT Press, Cambridge, MA). 
Campbell, J.Y., 1987, Does saving anticipate declining labor income? An alternative test of the permanent income hypothesis, Econometrica 55, 1249-1274.

Campbell, J.Y. and N.G. Mankiw, 1989, Consumption, income and interest rates: Reinterpreting the time series evidence, Harvard discussion paper no. 1435.

Campbell, J.Y. and R.J. Shiller, 1987, Cointegration and tests of present value models, Journal of Political Economy 95, 1062-1088.

Cochrane, J.H., 1989, The sensitivity of tests of the intertemporal allocation of consumption to near-rational alternatives, American Economic Review 79, 319-337.

Constantinedes, G.M., 1988, Habit formation: A resolution of the equity premium puzzle, Unpublished paper (Graduate School of Business, University of Chicago, Chicago, IL).

Deaton, A.S., 1986, Life-cycle models of consumption: Is the evidence consistent with the theory?, NBER working paper no. 1910.

Deaton, A., J. Ruiz-Castillo and D. Thomas, 1989, The influence of household composition on household expenditure patterns: Theory and Spanish evidence, Journal of Political Economy 97, 179-200.

Dornbusch, R., 1983, Real interest rates, home goods, and optimal external borrowing. Journal of Political Economy 91, 141-153.

Dwyer, G., 1986, Government deficits and the current account, Mimeo.

Engle, R.F. and C.W.J. Granger, 1987, Cointegration and error correction: Representation, estimation and testing, Econometrica 55, 251-276.

Feldstein, M. and C. Horioka, 1980, Domestic saving and international capital flows, Economic Journal 90, 314-329.

Flavin, M., 1988, The excess smoothness of consumption: Identification and interpretation, NBER working paper no. 2807.

Frenkel, J.A. and A. Razin, 1988, Fiscal policies and the world economy (MIT Press, Cambridge, MA).

Ghosh, A., 1988, How mobile is capital? Some simple tests, Mimeo.

Greenwood, J., 1983, Expectations, the exchange rate, and the current account, Journal of Monetary Economics 12, 543-569.

Hall, R.E., 1988, Intertemporal substitution in consumption, Journal of Political Economy 96, 339-357.

Johnson, D., 1986, Consumption, permanent income, and financial wealth in Canada: Empirical evidence on the intertemporal approach to the current account, Canadian Journal of Economics 19, 189-206.

Mankiw, N.G. and M.D. Shapiro, 1985, Trend, random walks and tests of the permanent income hypothesis, Journal of Monetary Economics 16, 165-174.

Obstfeld, M., 1986, Capital mobility in the world economy: Theory and measurement, Carnegie Rochester Series on Public Policy 24, 55-104.

Sachs, J., 198I, The current account and macroeconomic adjustment in the 1970s, Brookings Papers on Economic Activity, 201-268.

Sachs, J., 1982, The current account in the macroeconomic adjustment process, Scandinavian Journal of Economics 84, 147-159.

Sheffrin, S. and W.T. Woo, 1990, Testing an optimizing model of the current account via the consumption function, Journal of International Money and Finance, forthcoming.

West, K.D., 1987, A note on the power of least squares test for a unit root, Economics Letters $24,249-252$.

West, K.D., 1988, Asymptotic normality, when regressors have a unit root, Econometrica 56, $1397-1418$. 